Kontribusi Motivasi Berprestasi....(Rizky Andana Pohan)

\title{
KONTRIBUSI MOTIVASI BERPRESTASI DAN KONSEP DIRI TERHADAP KEGIATAN MERESPON DALAM PEMBELAJARAN SERTA IMPLIKASINYA DALAM BIMBINGAN DAN KONSELING
}

\author{
Oleh: Rizky Andana Pohan ${ }^{1}$, Rini Hayati², Dika Sahputra ${ }^{3}$ \\ (Dosen Universitas Muslim Nusantara Al-Washliyah Medan) \\ E-mail: andanapohan@gmail.com
}

\begin{abstract}
Abstrak
Penelitian ini bertujuan untuk: (1) mendeskripsikan motivasi berprestasi, (2) konsep diri, (3) kegiatan merespon dalam pembelajaran, (4) menguji kontribusi motivasi berprestasi terhadap kegiatan merespon dalam pembelajaran, (5) menguji kontribusi konsep diri terhadap kegiatan merespon dalam pembelajaran, dan (6) menguji kontribusi secara bersama-sama motivasi berprestasi dan konsep diri terhadap kegiatan merespon dalam pembelajaran. Penelitian ini menggunakan metode kuantitatif jenis deskriptif korelasional. Populasi penelitian adalah siswa kelas X dan XI SMA Negeri 1 Percut Sei Tuan sebanyak 700 orang, sampel sebanyak 254 orang, yang dipilih dengan teknik Proportional Stratified Random Sampling. Instrumen yang digunakan adalah skala model Likert. Data dianalisis dengan statistik deskriptif, regresi sederhana, dan regresi ganda. Temuan penelitian memperlihatkan bahwa: (1) secara ratarata gambaran motivasi berprestasi siswa berada pada kategori tinggi, (2) konsep diri siswa berada pada kategori positif, (3) kegiatan merespon dalam pembelajaran berada pada kategori tinggi, (4) terdapat kontribusi motivasi berprestasi terhadap kegiatan merespon sebesar $7.6 \%(R=0.277$, signifikansi 0.000), (5) terdapat kontribusi konsep diri terhadap kegiatan merespon sebesar $7.7 \%(R=0.279$, signifikansi 0.000), dan (6) terdapat kontribusi secara bersamasama motivasi berprestasi dan konsep diri terhadap kegiatan merespon dalam pembelajaran sebesar $11.7 \%(R=0.343$, signifikansi 0.000). Implikasi hasil penelitian tersebut dapat dijadikan sebagai analisis kebutuhan siswa untuk pembuatan program pelayanan bimbingan dan konseling di SMA Negeri 1 Percut Sei Tuan.
\end{abstract}

Kata Kunci : Motivasi Berprestasi, Konsep Diri, Kegiatan Merespon

$$
\begin{aligned}
& \text { CONTRIBUTION OF ACHIEVEMENT MOTIVATION AND SELF } \\
& \text { CONCEPT OF RESPONSE TO FREE LEARNING ACTIVITIES AND } \\
& \text { IMPLICATIONS OF MENTORING AND CONSELING }
\end{aligned}
$$

\begin{abstract}
This research is aimed to describe the contribution of the achievement motivation and self-concept towards responding activity in learning. This research applied quantitative method with a descriptive correlational. The population of this research were 700 students of SMA Negeri 1 Percut Sei Tuan in
\end{abstract}


grade $X$ and XI, and the samples were 254 students that were chosen by using proportional stratified random sampling. The instrument of the research was a likert scale. The data were analyzed by using descriptive statistics, simple and multiple regression. The research findings indicated that: (1) averagely, description of the achievement motivation was at high level, (2) self-concept was at positive level, (3) responding activity in learning was categorized at high level, (4) there was $7.6 \%(R=0.276$, on significance 0.000$)$ in achievement motivation contribution towards responding activity, (5) there was $7.7 \%(R=0.279$, significance 0.000$)$ in students' self-concept, (6) there was $11.7 \%(R=0.343$, on significance 0.000 ) in contribution together with achievement motivation and selfconcept towards responding activity in learning. The implication of this research can be made as a need assessment to make a program of guidance and counseling service in SMA Negeri 1 Percut Sei Tuan.

Keywords: Achievement Motivation, Self-Concept, Responding Activity

\section{A. PENDAHULUAN}

Pendidikan nasional memiliki tujuan yang sangat mulia yaitu untuk mencerdaskan kehidupan bangsa. Undang-Undang (UU) Nomor 20 Tahun 2003 mempunyai rumusan yang cukup luas dan strategis. Siswa semestinya memahami bahwa tujuan pendidikan tersebut adalah untuk dirinya, bukan kemauan orangtua maupun guru. Jika prinsip ini dapat dipahami, maka sudah bisa dipastikan siswa sebagai pembelajar, akan mampu menjadi lebih mandiri dan aktif menemukan sendiri pengetahuan yang dibutuhkannya.

Salah satu indikator keaktifan dan kemandirian dalam belajar adalah kemampuan siswa untuk merespon segala bentuk interaksi yang terjadi pada saat pembelajaran. Prayitno dkk. (2002:5) mengemukakan bahwa kegiatan merespon merujuk kepada tiga bentuk kegiatan yang cukup esensial dalam pembelajaran yaitu: menanya, menjawab pertanyaan, dan mengemukakan pendapat. Kegiatan merespon dalam pembelajaran menjadi sebuah jembatan pengetahuan untuk melangkah pada tahap berikutnya. Hal tersebut terlihat pada pengembangan Kurikulum 2013 dengan pendekatan scientific. Menanya menjadi alur kegiatan yang kedua, sekaligus menjadi acuan bagi guru, apakah siswa telah mengamati dengan baik. Indikator merespon adalah pertanyaan, pendapat, maupun jawaban yang diutarakan oleh siswa dalam proses pembelajaran. Tahap yang terakhir 
adalah mengkomunikasikan, pada tahap ini siswa juga dituntut untuk mampu memberikan respon. Kegiatan merespon merupakan salah satu tolok ukur kemajuan belajar, yang dimulai dari mengamati, menanya, mencobakan, mengasosiasikan sampai pada tahap mengkomunikasikan (Permendikbud Nomor 81A Tahun 2013). Jika siswa mampu merespon dengan baik pada saat pembelajaran, maka rekonstruksi pemikiran dan pengetahuan yang didapatnya, akan lebih mudah dipahami dan diketahui oleh guru (Hosman, 2014:50).

Berdasarkan study pendahuluan mengenai kegiatan merespon dalam pembelajaran, ditemukan adanya data yang bervariasi. Temuan beberapa penelitian menunjukkan bahwa semakin tinggi tingkat kelas, semakin sedikit siswa untuk bertanya di kelas pada saat pembelajaran (Good dalam Marbach-Ad dan Sokolove, 2000:855). Hasil ini juga sesuai dengan penelitian beberapa mahasiswa Universitas Pendidikan Indonesia (UPI) yang salah satunya menyebutkan bahwa, dari seluruh pertanyaan yang muncul pada saat pembelajaran, sekitar 95\% pertanyaan berasal dari guru, sisanya hanya 5\% pertanyaan yang diungkapkan oleh siswa (Widodo dalam Navtalie, 2014:2).

Penelitian Daharnis dkk. (2014) mendeskripsikan keadaan belajar Siswa SMA se Sumatera Barat, menunjukkan bahwa kegiatan merespon dalam pembelajaran secara rata-rata masih berada dalam kategori sedang. Penelitian Pohan (2016:62) juga menunjukkan bahwa kegiatan merespon siswa di SMA N 8 Padang berada pada kategori tinggi. Hal ini menunjukkan bahwa kegiatan merespon yang dilakukan oleh siswa, masih menjadi masalah yang nyata dalam pembelajaran. Kegiatan merespon merupakan bagian dari proses kegiatan belajar yang termasuk dalam aktivitas belajar siswa di kelas (Dunkin dan Biddle dalam Garton dkk., 2000:11). Kegiatan belajar siswa tersebut tentunya dipengaruhi oleh beberapa variabel yaitu: presage variables dan context variables (Elliot dkk., 1996:21). Kegiatan merespon menjadi salah satu bagian dari process variables yang dipengaruhi oleh variabel karakteristik siswa (context variables). Karakteristik siswa meliputi berbagai hal seperti inteligensi, motivasi, kelas sosial, tingkat aspirasi, persepsi, kepercayaan diri, sikap, dll. (Nirwana, 2003:1). 
Beberapa variabel yang diduga memberikan kontribusi terhadap kegiatan merespon siswa dalam pembelajaran yaitu motivasi berprestasi dan konsep diri.

Motivasi berprestasi merupakan salah satu hal yang harus ada dalam diri siswa. Santrock (2003:474) menjelaskan bahwa, "Motivasi berprestasi adalah keinginan untuk menyelesaikan sesuatu, untuk mencapai suatu standar kesuksesan, dan melakukan suatu usaha dengan tujuan untuk mencapai kesuksesan”. Motivasi berprestasi akan menghasilkan sebuah dorongan yang positif sehingga diduga akan mempengaruhi kegiatan merespon dalam pembelajaran. Motivasi berprestasi diduga akan mempengaruhi tingkah laku. Untuk itu selain motivasi berprestasi diperlukan juga konsep diri yang positif untuk memperkuat keinginan siswa dalam merespon.

Menurut Hurlock (1980:232) konsep diri adalah gambaran yang dimiliki orang tentang dirinya. Mead (dalam Burns, 1993:18) menjelaskan pandangan, penilaian, dan perasaan individu mengenai dirinya yang timbul sebagai hasil dari suatu interaksi sosial disebut sebagai konsep diri. Konsep diri menunjang individu menjalani hidupnya, karena setiap individu tahu bagaimana cara memandang dirinya begitu pula menjalani kehidupannnya. Pada akhirnya konsep diri yang positif diduga akan meningkatkan kegiatan merespon siswa.

Berdasarkan uraian di atas, terlihat adanya keterkaitan motivasi berprestasi dan konsep diri secara bersama-sama berhubungan terhadap kegiatan merespon dalam pembelajaran. Namun, bagaimana besar kecilnya kontribusi antara faktorfaktor tersebut, maka perlu dilakukan penelitian. Hasil dari penelitian inilah yang akan dijadikan need assessment dalam penyusunan program BK. Hal inilah yang menjadi dasar penelitian ini dilakukan, karena belum adanya temuan penelitian yang menunjukkan seberapa besar kontribusi motivasi berprestasi dan konsep diri terhadap kegiatan merespon dalam pembelajaran. Tujuan penelitian ini adalah sebagai berikut: (1) mendeskripsikan motivasi berprestasi siswa, (2) mendeskripsikan konsep diri siswa, (3) mendeskripsikan kegiatan merespon dalam pembelajaran, (4) menguji kontribusi motivasi berprestasi terhadap kegiatan merespon dalam pembelajaran, (5) menguji kontribusi konsep diri 
Kontribusi Motivasi Berprestasi dan Konsep Diri....(Rizky Andana Pohan)

terhadap kegiatan merespon dalam pembelajaran, (6) menguji kontribusi secara bersama-sama motivasi berprstasi dan konsep diri terhadap kegiatan merespon dalam pembelajaran.

\section{B. METODOLOGI PENELITIAN}

Penelitian ini menggunakan metode kuantitatif jenis deskriptif korelasional. Populasi penelitian adalah siswa kelas X dan XI SMA Negeri 1 Percut Sei Tuan yang berjumlah 700 orang, sampel berjumlah 254 orang, yang dipilih dengan teknik proportional stratified random sampling. Instrumen yang digunakan adalah skala model likert. Data dianalisis dengan statistik deskriptif, regresi sederhana dan ganda. Analisis data dibantu dengan menggunakan program SPSS versi 17.00.

\section{HASIL DAN PEMBAHASAN}

\section{Deskripsi Data}

Data dalam penelitian ini meliputi variabel motivasi berprestasi $\left(\mathrm{X}_{1}\right)$, konsep diri $\left(\mathrm{X}_{2}\right)$, dan kegiatan merespon dalam pembelajaran $(\mathrm{Y})$. Berikut ini dikemukakan deskripsi data hasil penelitian.

1. Motivasi Berprestasi $\left(X_{1}\right)$

Deskripsi data motivasi berprestasi yang berjumlah 254 responden dapat dilihat pada Tabel 1.

Tabel 1. Distribusi Frekuensi dan Persentase Motivasi Berprestasi

\begin{tabular}{|c|l|c|c|}
\hline Interval Skor & \multicolumn{1}{|c|}{ Kategori } & Frekuensi & $\mathbf{\%}$ \\
\hline$\geq 130$ & Sangat Tinggi (ST) & 20 & 8 \\
\hline $105-129$ & Tinggi (T) & 175 & 69 \\
\hline $80-104$ & Sedang (S) & 56 & 22 \\
\hline $55-79$ & Rendah (R) & 3 & 1 \\
\hline$\leq 54$ & Sangat Rendah (SR) & 0 & 0 \\
\hline \multicolumn{2}{|c|}{ Jumlah } & 254 & 100 \\
\hline
\end{tabular}

Tabel di atas menjelaskan bahwa sebagian besar siswa memiliki motivasi berprestasi yang tinggi.

\section{Konsep Diri $\left(X_{2}\right)$}


Wahana Didaktika Vol. 16 No.2 Mei 2017 : 145-161

Deskripsi data konsep diri yang berjumlah 254 responden dapat dilihat pada Tabel 2.

Tabel 2. Distribusi Frekuensi dan Persentase Konsep Diri

\begin{tabular}{|c|l|c|c|}
\hline Interval Skor & \multicolumn{1}{|c|}{ Kategori } & Frekuensi & $\mathbf{\%}$ \\
\hline$\geq 101$ & Sangat Positif & 9 & 3.5 \\
\hline $82-100$ & Positif & 139 & 54.7 \\
\hline $63-81$ & Cukup Positif & 101 & 39.8 \\
\hline $44-62$ & Tidak Positif & 4 & 1.6 \\
\hline$\leq 43$ & Sangat Tidak Positif & 0 & 0 \\
\hline & Total & 254 & 100 \\
\hline
\end{tabular}

Tabel di atas menjelaskan bahwa sebagian besar siswa memiliki konsep diri yang positif.

\section{Kegiatan Merespon dalam Pembelajaran}

Deskripsi data kegiatan merespon dalam pembelajaran yang berjumlah 254 responden dapat dilihat pada Tabel .3

Tabel 3. Distribusi Frekuensi dan Persentase Kegiatan Merespon

\begin{tabular}{|c|l|c|c|}
\hline Interval Skor & \multicolumn{1}{|c|}{ Kategori } & Frekuensi & $\mathbf{\%}$ \\
\hline$\geq 67$ & Sangat Tinggi & 35 & 13.78 \\
\hline $54-66$ & Tinggi & 138 & 54.33 \\
\hline $41-53$ & Sedang & 68 & 25.19 \\
\hline $28-40$ & Rendah & 13 & 5.11 \\
\hline$\leq 27$ & Sangat Rendah & 0 & 0 \\
\hline \multicolumn{2}{|c|}{ Total } & 254 & 100 \\
\hline
\end{tabular}

Tabel di atas menjelaskan bahwa sebagian besar kegiatan merespon yang dilakukan oleh siswa berada pada kategori tinggi.

\section{Pengujian Persyaratan Analisis Data}

Uji persyaratan analisis yang dilakukan pada data penelitian ini adalah uji normalitas, uji linieritas, dan uji multikolinieritas.

\section{Uji Normalitas}

Pengujian normalitas dilakukan dengan menggunakan metode KolmogorovSmirnov. Jika Asymp. Sig. atau P-value > dari 0.05 (taraf signifikansi), maka data berasal dari populasi yang berdistribusi normal. Hasil uji normalitas data nilai 
Kontribusi Motivasi Berprestasi dan Konsep Diri....(Rizky Andana Pohan)

Asymp. Sig. Motivasi berprestasi sebesar 0.265, konsep diri sebesar 0.156, dan kegiatan merespon dalam pembelajaran sebesar 0.352. Berarti ketiga data variabel penelitian berdistribusi normal.

\section{Uji Linieritas}

Uji linieritas dalam penelitian ini memanfaatkan program SPSS versi 17.00. Jika nilai $F_{\text {hitung }} \geq F_{\text {tabel}}$, maka dinyatakan linier, dan sebaliknya jika nilai $F_{\text {hitung }}<$

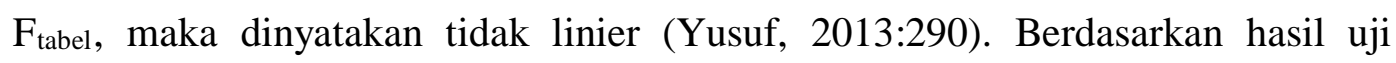
linieritas, didapatkan hasil bahwa hubungan motivasi berprestasi dengan kegiatan merespon dalam pembelajaran adalah linier dengan $F_{\text {hitung }}$ (18.743) $>F_{\text {tabel }}$ (3.89). Data hubungan konsep diri dengan kegiatan merespon dalam pembelajaran juga linier dengan $F_{\text {hitung }}(17.412)>F_{\text {tabel }}$ (3.89).

\section{Uji Multikolinieritas}

Berdasarkan uji multikolinieritas diperoleh nilai VIF motivasi berprestasi sebesar 1.127 dan nilai VIF konsep diri sebesar $1.127<10$. Berdasarkan hasil tersebut dapat disimpulkan tidak terjadi multikolinieritas antara variabel motivasi berprestasi dengan konsep diri.

\section{Kontribusi Motivasi Berprestasi dan Konsep Diri terhadap Kegiatan Merespon dalam Pembelajaran}

\section{Kontribusi Motivasi Berprestasi terhadap Kegiatan Merespon dalam Pembelajaran}

Hasil analisis kontribusi motivasi berprestasi terhadap kegiatan merespon dalam pembelajaran dapat dilihat pada Tabel 4.

Tabel 4. Hasil Analisis Regresi Sederhana dan Uji Signifikansi $X_{1}$ terhadap $Y$

\begin{tabular}{|c|c|c|c|}
\hline Model & R & R Square & Sig. \\
\hline $\mathrm{X}_{1}-\mathrm{Y}$ & 0.277 & 0.076 & 0.000 \\
\hline
\end{tabular}

Pada Tabel 4 dapat dilihat bahwa nilai R sebesar 0.277 yang menunjukkan koefisien regresi antara motivasi berprestasi terhadap kegiatan merespon dalam pembelajaran, dengan taraf signifikan 0.000. Nilai $R$ Square $\left(R^{2}\right)$ sebesar 0.076, ini berarti 7.6\% variasi tinggi-rendahnya kegiatan merespon dalam pembelajaran 
dapat dijelaskan oleh motivasi berprestasi, sedangkan sisanya 92,4\% dijelaskan oleh variabel lain.

\section{Kontribusi Konsep Diri terhadap Kegiatan Merespon dalam Pembelajaran}

Hasil analisis kontribusi konsep diri terhadap kegiatan merespon dalam pembelajaran dapat dilihat pada Tabel 5.

Tabel 5. Hasil Analisis Regresi Sederhana dan Uji Signifikansi $X_{2}$ terhadap $Y$

\begin{tabular}{|c|c|c|c|}
\hline Model & R & R Square & Sig. \\
\hline $\mathrm{X}_{2}-\mathrm{Y}$ & 0.279 & 0.077 & 0.000 \\
\hline
\end{tabular}

Pada Tabel 5 dapat dilihat bahwa nilai R sebesar 0.279 yang menunjukkan koefisien regresi antara konsep diri terhadap kegiatan merespon dalam pembelajaran, dengan taraf signifikan 0,000 . Nilai $R$ Square $\left(R^{2}\right)$ sebesar 0.077 , ini berarti 7.7\% variasi tinggi rendahnya kegiatan merespon dalam pembelajaran dapat dijelaskan oleh konsep diri tentang kegiatan merespon, sedangkan sisanya 92.3\% dijelaskan oleh variabel lain.

\section{Kontribusi Kepercayaan Diri dan Persepsi Siswa terhadap Kegiatan Merespon dalam Pembelajaran}

Hasil analisis kontribusi motivasi berprestasi dan konsep diri terhadap kegiatan merespon dalam pembelajaran dapat dilihat pada Tabel 6.

Tabel 6. Hasil Analisis Regresi Ganda dan Uji Signifikansi $X_{1}$ dan $X_{2}$ terhadap $Y$

\begin{tabular}{|c|c|c|c|}
\hline Model & $\mathbf{R}$ & $\boldsymbol{R}$ Square & Sig. \\
\hline $\mathrm{X}_{1}, \mathrm{X}_{2}-\mathrm{Y}$ & 0.343 & 0.117 & 0.000 \\
\hline
\end{tabular}

Pada Tabel 6 dapat dilihat bahwa nilai R sebesar 0.343 yang menunjukkan koefisien regresi ganda antara motivasi berprestasi dan konsep diri terhadap kegiatan merespon dalam pembelajaran, dengan taraf signifikan 0.000. Nilai $R$ Square $\left(R^{2}\right)$ sebesar 0.117 , ini berarti $11.7 \%$ variasi tinggi rendahnya kepercayaan diri dapat dijelaskan secara bersama-sama oleh kepercayaan diri dan persepsi siswa, sedangkan sisanya $88.3 \%$ dijelaskan oleh variabel lain yang belum diteliti dalam penelitian ini.

\section{PEMBAHASAN}


Kontribusi Motivasi Berprestasi dan Konsep Diri....(Rizky Andana Pohan)

\section{Motivasi Berprestasi}

Hasil analisis data penelitian menunjukkan bahwa secara rata-rata keseluruhan motivasi berprestasi siswa berada dalam kategori tinggi. Hal ini berarti motivasi berprestasi siswa dalam belajar sudah baik. Siswa sampai pada kondisi motivasi berprestasi tinggi tersebut tidaklah mudah. Motivasi berprestasi merupakan suatu hal yang kompleks dan sangat dibutuhkan oleh siswa terkhusus dalam kegiatan merespon pada saat pembelajaran di kelas.

Berdasarkan data penelitian Guru BK atau Konselor memegang peranan penting untuk mengembangkan potensi motivasi berprestasi tinggi yang telah dimiliki oleh siswa. Bagaimanapun motivasi berprestasi bukanlah suatu hal yang muncul begitu saja dalam diri siswa. Motivasi berprestasi merupakan daya penggerak dalam diri siswa untuk dapat mewujudkan dan mengungkapkan sesuatu yang ada di dalam dirinya. Sebagaimana Oktasari (2016) menyatakan bahwa "Siswa yang memiliki motivasi berprestasi yang tinggi, akan beranggapan bahwa prestasi merupakan suatu hal yang harus diraih, diperjuangkan, dan dibanggakan. Sedangkan, bagi siswa yang memiliki motivasi berprestasi rendah, meningkatkan prestasinya merupakan suatu hal yang sulit untuk diwujudkan”.

\section{Konsep Diri}

Berdasarkan hasil analisis data penelitian, bahwa secara rata-rata keseluruhan konsep diri berada pada kategori positif. Konsep diri positif yang dimiliki oleh siswa merupakan sebuah modal yang baik dalam proses pembelajaran. Berdasarkan indikator secara keseluruhan aspek fisik, sosial, dan moral berada pada kategori positif, namun pada aspek kognitif berada pada kategori cukup positif. Hal ini dapat dipahami bahwa konsep diri merupakan kondisi individu yang trus bergerak sesuai dengan objek yang menjadi fokus kegiatan, pada penelitian ini adalah konsep diri dalam belajar. Hal tersebut sesuai dengan pendapat Saragi (2016) yang menyatakan bahwa "konseptualisasi diri yang tidak sehat yang penuh dengan perasaan inferioritas, tidak memadai, kegagalan, tidak berharga, dan tidak aman juga dipelajari dan karena dapat diganti, atau tidak dipelajari dengan cara-cara sehat yang dipelajari digantikan”. 
Hal ini mengindikasikan bahwa konsep diri dapat berubah sejalan dengan perkembangan diri individu itu sendiri.

Dengan demikian, data hasil penelitian ini dapat dijadikan Guru BK atau Konselor sebagai suatu proses analisis kebutuhan siswa. Analisis kebutuhan inilah yang kemudian dijadikan Guru BK atau Konselor sebagai bahan pembuatan program BK. Sehingga, Guru BK atau Konselor mampu mengembangkan konsep diri yang positif dalam diri siswa. Jika hal ini dilakukan secara berkesinambungan, maka siswa akan merasakan dampak yang nyata bagi penguasaan materi pelajarannya di kelas.

\section{Kegiatan Merespon dalam Pembelajaran}

Hasil analisis data penelitian menunjukkan bahwa secara rata-rata keseluruhan kegiatan merespon dalam pembelajaran berada pada kategori tinggi. Berdasarkan pencapaian masing-masing indikator diketahui bahwa semua indikator yaitu menanya, menjawab, dan mengemukakan pendapat berada pada kategori tinggi. Hasil ini memberikan gambaran bahwa kegiatan merespon di SMA Negeri 1 Percut Sei Tuan sedikit lebih baik jika dibandingkan dengan keadaan rata-rata kegiatan merespon Siswa SMA se Sumatera Barat yang berada pada ketegori sedang (Daharnis dkk., 2014). Gambaran kegiatan merepon pada penelitian ini juga sama dengan kategori tinggi dengan hasil penelitian mengenai kegiatan merespon di SMA Negeri 8 Padang maupun SMA Al-Washliyah 3 Medan (Pohan: 2016; 2018).

Keadaan seperti ini merupakan hal yang sangat baik, ini menjadi tanda bahwa alur pembelajaran yang pertama mengamati kemudian yang kedua menanya sesuai dengan pendekatan ilmiah dalam pengembangan Kurikukulum 2013 telah berjalan dengan baik (Permendikbud Nomor 81A Tahun 2013). Data penelitian ini mempermudah Guru BK atau Konselor dalam membuat analisis kebutuhan mengenai kegiatan merespon dalam pembelajaran. Selanjutnya, data analisis kebutuhan akan dijadikan program pelayanan BK di sekolah.

4. Kontribusi Motivasi Berprestasi terhadap Kegiatan Merespon dalam Pembelajaran 
Kontribusi Motivasi Berprestasi dan Konsep Diri....(Rizky Andana Pohan)

Hasil penelitian menunjukkan bahwa motivasi berprestasi berkontribusi secara signifikan terhadap kegiatan merespon dalam pembelajaran. Temuan ini diperoleh berdasarkan rangkaian analisis data yang menunjukkan bahwa kontribusi motivasi berprestasi terhadap kegiatan merespon dalam pembelajaran sebesar 7.6\%. Artinya, motivasi berprestasi merupakan salah satu faktor yang berkontribusi terhadap kegiatan merespon dalam pembelajaran. Kegiatan merespon merupakan aktivitas yang melibatkan verbal siswa. Siswa dalam belajar memberikan respon dalam bentuk menanya, menjawab, dan mengemukakan pendapat. Untuk itu motivasi berprestasi sangat diperlukan agar siswa mau memberikan respon dalam pembelajaran. Hal tersebut tergambar pada indikator penelitian yaitu memperhatikan umpan balik dan berusaha keras untuk mencapai satandard yang telah ditentukan dengan rata-rata capaian tinggi. Hal ini dapat dipahami bahwa siswa yang memiliki motivasi berprestasi yang tinggi tentu selalu memperhatikan situasi di kelas dengan terus memperhatikan umpan balik yang akan diberikan. Usaha memberikan umpan balik tersebut merupakan wujud dari respon yang diberikan saat pembelajaran baik pertanyaan, jawaban, maupun pendapat.

Hal tersebut sesuai dengan pendapat Sardiman (2012:75) yang menyatakan bahwa motivasi memiliki peranan yang khas dalam hal penumbuhan gairah, merasa senang, dan semangat untuk belajar. Siswa yang memiliki motivasi yang kuat, akan mempunyai banyak energi untuk melakukan kegiatan belajar salah satunya adalah merespon, sebaliknya siswa yang memiliki motivasi yang rendah, akan mempunyai sedikit energi untuk merespon dalam belajar.

\section{Kontribusi Konsep Diri terhadap Kegiatan Merespon dalam Pembelajaran}

Hasil penelitian menunjukkan bahwa konsep diri siswa berkontribusi secara signifikan terhadap kegiatan merespon dalam pembelajaran. Temuan ini diperoleh berdasarkan rangkaian analisis data yang menunjukkan bahwa kontribusi konsep diri terhadap kegiatan merespon dalam pembelajaran sebesar 7.7\%. Artinya, 
konsep diri merupakan salah satu faktor yang berkontribusi terhadap kegiatan merespon dalam pembelajaran.

Merujuk pada data penelitian ini dapat dipahami bahwa semakin positif konsep diri siswa semakin tinggi pula kegiatan merespon dalam pembelajaran. Hal ini terlihat pada beberapa indikator konsep diri yang memiliki capaian positif yaitu aspek fisik, sosial, moral. Sementara aspek kognitif memiliki capaian cukup positif. Hal ini dapat dipahami bahwa jika konsep diri siswa tentang dirinya sudah positif maka tidak ada kendala dan halangan bagi siswa untuk dapat merespon dengan baik pula.

Berdasarkan pemaparan di atas, dapat dipahami bahwa begitu berpengaruhnya konsep diri dalam menentukan keberhasilan kegiatan merespon dalam pembelajaran. Aktifnya siswa merespon salah satunya dipengaruhi oleh konsep diri. Oleh sebab itu, Guru BK atau Konselor dan guru mata pelajaran perlu memahami bahwa untuk meningkatkan kegiatan merespon dalam pembelajaran, maka konsep diri siswa dapat diubah menjadi lebih positif. Hal ini sesuai dengan pendapat Saragi (2016) bahwa konsep diri (dalam hal ini yang berhubungan dengan akademik) merupakan salah satu faktor penting yang mempengaruhi tingkah laku keberhasilan dalam belajar.

\section{Kontribusi Motivasi Berprestasi dan Konsep Diri terhadap Kegiatan Merespon dalam Pembelajaran}

Hasil penelitian menunjukkan bahwa motivasi berprestasi dan konsep diri secara bersama-sama berkontribusi secara signifikan terhadap kegiatan merespon dalam pembelajaran. Temuan ini diperoleh berdasarkan rangkaian analisis data yang menunjukkan bahwa kontribusi motivasi berprestasi dan konsep diri terhadap kegiatan merespon dalam pembelajaran sebesar $11.7 \%$. Berdasarkan hasil penelitian diperoleh gambaran bahwa motivasi berprestasi dan konsep diri siswa tidak terlalu berbeda memberikan kontribusi terhadap kegiatan merespon dalam pembelajaran.

Motivasi berprestasi merupakan dorongan atau keinginan untuk menyelesaikan suatu kegiatan atau tugas sebaik-baiknya berdasarkan standar 
keunggulan dengan mengerahkan semua kemampuan, kekuatan dan keterampilan yang ada dalam dirinya, tidak mudah menyerah, dan mencapai target sesuai dengan tujuan yang ditetapkan (Oktasari, 2016). Proses pembelajaran di kelas tentunya melibatkan banyak interaksi. Interaksi-interaksi yang terjadi di kelas melibatkan banyak pihak terutama siswa dengan siswa maupun siswa dengan guru. Merespon merupakan suatu kegiatan yang didalamnya terjadi interaksi. Untuk dapat merespon seorang siswa tentunya harus memiliki dorongan dan keinginan yang kuat dalam dirinya untuk mendapatkan ataupun memperoleh ilmu pengetahuan dalam belajar. Untuk dapat merespon tersebutlah diperlukan motivasi berprestasi yang tinggi dalam diri siswa, sehingga setiap interaksi dalam susana pembelajaran dapat dicermati dengan baik oleh siswa.

Motivasi berprestasi merupakan salah satu faktor intrinsik yang mempengaruhi kegiatan merespon dalam pembelajaran. Ternyata motivasi berprestasi saja belum cukup, konsep diri merupakan salah satu variabel yang berkontribusi secara signifikan terhadap kegiatan merespon dalam pembelajaran. Konsep diri merupakan salah satu variabel intrinsik yang mempengaruhi kegiatan belajar siswa salah satunya adalah kegiatan merespon. Menurut Saragi (2016) bahwa konsep diri dapat didefinisikan sebagai pemahaman, penilaian, dan penghargaan/penerimaan individu terhadap dirinya sendiri, meliputi: kondisi fisik, hubungan sosial, keadaan emosional, dan kemampuan intelektual. Berdasarkan pendapat tersebut dapat dipahami bahwa semakin positif konsep diri yang dimiliki oleh siswa dalam belajar semakin tinggi pula kegiatan merespon yang dilakukannya. Sebaliknya jika siswa memandang dirinya dengan konsep diri yang negatif maka semakin rendah pula intensitas kegiatan merespon yang dilakukannya dalam belajar.

Berdasarkan nilai $R^{2}$ kegiatan merespon dalam pembelajaran dipengaruhi sebesar $11.7 \%$ oleh motivasi berprestasi dan konsep diri, kemudian $88.3 \%$ lagi kemungkinan dipengaruhi oleh faktor lain yang belum diteliti pada penelitian ini. Hal ini terlihat bahwa motivasi berprestasi dan konsep diri secara bersama-sama secara signifikan tidak terlalu besar mempengaruhi kegiatan merespon dalam 
pembelajaran. Keadaan ini dapat dipahami, karena sesungguhnya masih banyak variabel lainnya yang mempengaruhi kegiatan merespon dalam pembelajaran.

Bila merujuk pada teori Elliot dkk. (1996:21) bahwa beberapa faktor yang mempengaruhi kegiatan merespon dalam pembelajaran kemungkinan dari karakteristik siswa lainnya, proses pembelajaran, kondisi sekolah maupun karakteristik guru, dll. Terkhusus pada karakteristik siswa yang didalamnya terdapat kemampuan dan keterampilan yang diduga sangat mempengaruhi terhadap kegiatan merespon dalam pembelajaran. Hal tersebut dapat dipahami karena beberapa aktivitas dalam kegiatan merespon menuntut siswa untuk memiliki pengetahuan dasar, yaitu pada kegiatan menjawab pertanyaan dan mengemukakan pendapat.

Beberapa paparan di atas membuktikan bahwa motivasi berprestasi dan konsep diri secara bersama-sama memberikan kontribusi yang signifikan terhadap kegiatan merespon dalam pembelajaran. Dengan demikian, untuk meningkatkan kegiatan merespon dalam pembelajaran, dapat diupayakan dengan meningkatkan motivasi berprestasi dan mengupayakan siswa mempunyai konsep diri yang positif dalam pembelajaran.

\section{KESIMPULAN DAN SARAN}

Berdasarkan temuan dan pembahasan hasil penelitian, maka dapat dikemukakan kesimpulan sebagai berikut:

1. Secara rata-rata motivasi berprestasi Siswa SMA Negeri 1 Percut Sei Tuan berada pada kategori tinggi.

2. Secara rata-rata konsep diri Siswa SMA Negeri 1 Percut Sei Tuan berada pada kategori positif.

3. Secara rata-rata kegiatan merespon dalam pembelajaran Siswa SMA Negeri 1 Percut Sei Tuan berada pada kategori tinggi.

4. Motivasi berprestasi memberikan kontribusi secara signifikan terhadap kegiatan merespon dalam pembelajaran di SMA Negeri 1 Percut Sei Tuan yaitu sebesar 7.6\% $\left(\mathrm{R}=0.277 R^{2}=0.076\right.$, dan signifikansi 0.000$)$. Artinya, 
Kontribusi Motivasi Berprestasi dan Konsep Diri....(Rizky Andana Pohan)

apabila motivasi berprestasi ditingkatkan menjadi lebih tinggi, maka kegiatan merespon dalam pembelajaran akan meningkat menjadi lebih tinggi, atau sebaliknya.

5. Konsep diri memberikan kontribusi secara signifikan terhadap kegiatan merespon dalam pembelajaran di SMA Negeri 1 Percut Sei Tuan yaitu sebesar 7.7\% $\left(\mathrm{R}=0.279 R^{2}=0.077\right.$, dan signifikansi 0.000). Artinya, apabila konsep diri ditingkatkan menjadi lebih positif, maka kegiatan merespon dalam pembelajaran akan meningkat menjadi lebih tinggi, atau sebaliknya.

6. Motivasi berprestasi dan konsep diri secara bersama-sama memberikan kontribusi secara signifikan terhadap kegiatan merespon dalam pembelajaran di SMA Negeri 1 Percut Sei Tuan yaitu sebesar $11.7 \%\left(\mathrm{R}=0.343, R^{2}=0.117\right.$, dan signifikansi 0.000). Artinya, tinggi rendahnya kegiatan merespon dalam pembelajaran tidak hanya dipengaruhi oleh satu variabel saja (motivasi berprestasi dan konsep diri), namun dipengaruhi secara bersama-sama oleh motivasi berprestasi dan konsep diri. Atau dengan kata lain dapat dikatakan bahwa semakin tinggi motivasi berprestasi dan semakin positif konsep diri, maka semakin tinggi kegiatan merespon dalam pembelajaran. Hal ini berarti variabel motivasi berprestasi dan konsep diri akan lebih efektif jika dikombinasikan secara bersama-sama sebagai prediktor untuk meningkatkan kegiatan merespon dalam pembelajaran daripada hanya satu variabel saja.

Berdasarkan hasil penelitian, pembahasan, dan kesimpulan yang telah dikemukakan sebelumnya, maka terdapat beberapa saran yang dapat direkomendasikan sebagai berikut:

1. Kepada Guru BK atau Konselor di sekolah disarankan untuk tetap meningkatkan dan mengembangkan motivasi berprestasi dan konsep diri sehingga berdampak pada peningkatan kegiatan merespon dalam pembelajaran.

2. Kepada guru mata pelajaran di sekolah disarankan untuk tetap meningkatkan dan memperhatikan kegiatan merespon dalam pembelajaran. 
3. Kepada kepala sekolah disarankan untuk dapat memberikan dukungan penuh kepada Guru BK atau Konselor, dengan memfasilitasi sebaik mungkin pelaksanaan masuk kelas 2 jam pembelajaran setiap minggu, maupun pelaksanaan layanan BK di luar jam pembelajaran

\section{DAFTAR PUSTAKA}

Burns, R.B. 1993. Konsep Diri: Teori, pengukuran, perkembangan, dan perilaku. Terjemahan oleh Eddy. 1993. Jakarta: Arcan.

Daharnis. 2005. "Hubungan Aspirasi, Persepsi, Lokus Kendali, Status Sosial Ekonomi, Lingkungan Belajar, dan Pembelajaran dengan Kegiatan Belajar Mahasiswa”. Disertasi tidak diterbitkan. Malang: Program Pascasarjana Universitas Negeri Malang.

Daharnis dkk. 2014. Model Program Pengembangan Kegiatan Belajar Siswa SMA Sumatera Barat. Padang: Lembaga Penelitian Universitas Negeri Padang.

Elliot, S. N. dkk. 1996. Educational Psychology. USA: Brown dan Benchmark.

Garton, B. L. dkk. 2000. "Learning Styles, Teaching Performance, and Student Achievement: A relational study". Journal of Agricultural Education, (Online), Vol. 40, No. 3, (http://citeseerx.ist.psu.edu/messages/, diakses 6 April 2015).

Hosman, M. 2014. Pendekatan Saintifik dan Kontekstual dalam Pembelajaran Abad 21: Kunci sukses implementasi kurikulum 2013. Jakarta: Ghalia Indonesia.

Hurlock, E.B. 1980. Perkembangan Anak Edisi Keenam. Terjemahan oleh Med Meitasari Tjandrasa. Jakarta: Erlangga.

Marbach-Ad, G. dan Sokolove, P. G. 2000. “Can Undergraduate Biology Students Learn to Ask Higher Level Questions?”. Journal of Research in Science Teaching, (Online), Vol.37, No. 8, (854-870), (http://onlinelibrary.wiley.com/, diakses 24 Februari 2015).

Marbach-Ad, G. dan Sokolove, P. G. 2000. “Good Science Begin With Good Questions”. Journal of College Science Teaching, (Online), Vol. 30, No. 3, (http://wiki.biologyscholars.org/, diakses 24 Februari 2015).

Navtalie, A. 2014. "Penerapan Question Formulating Tehnique dalam Upaya Meningkatkan Keterampilan Bertanya Siswa pada Pembelajaran Sistem Imun”. Tesis tidak diterbitkan. Bandung: Program Pascasarjana Universitas Pendidikan Indonesia. 
Nirwana, H. 2003. "Hubungan Tingkat Aspirasi dan Persepsi tentang Belajar dengan Hasil Belajar Matematika Siswa SMU yang Berlatar Belakang Budaya Minangkabau dan Batak”. Disertasi tidak diterbitkan. Malang: Program Pascasarjana Universitas Negeri Malang.

Oktasari, M. 2016. "Hubungan Persepsi Siswa Tentang Dukungan Sosial Teman Sebaya Terhadap Motivasi Berprestasi Siswa”. Journal Biblio Couns (Jurnal Kajian Konseling dan Pendidikan), Vol 1 No 1.

Permendikbud Nomor 81 A Tahun 2013 tentang Implementasi Kurikulum. Jakarta: Kemendikbud RI.

Pohan, Rizky Andana. 2016. “Kontribusi nsep diri dan Persepsi Siswa Terhadap Kegiatan Merespon dalam Pembelajaran Serta Implikasinya dalam Bimbingan dan Konseling”. Jurnal Penelitian Bimbingan dan Konseling (On line), Vol 1 No. 2.

Prayitno dkk. 2002. Seri Latihan Keterampilan Belajar. Jakarta: Dirjen Dikti PPMPT Depdiknas.

Santrock. 2003. Adolencence Perkembangan Remaja. Terjemahan oleh Achmad Chusairi dan Juda Damanik. Jakarta: Erlangga.

Saragi, MPD. 2016. Kontribusi Konsep Diri dan Dukungan Orangtua Terhadap Motivasi Belajar Siswa. Jurnal Konselor (online). Vol. 5 No 1.

Sardiman. 2012. Interaksi dan Motivasi Belajar Mengajar. Jakarta: Rajawali Pers.

Undang-Undang Nomor 20 Tahun 2003 tentang Sistem Pendidikan Nasional. Jakarta: Depdiknas RI.

Yusuf, A. M. 2013. Metode Penelitian Kuantitatif, Kualitatif, dan Penelitian Gabungan. Padang: UNP Press. 